\title{
A WAR BY OTHER MEANS? CONCEPTIONS OF DEMOCRACY AND THE ELECTION LAW IN BOSNIA AND HERZEGOVINA
}

\author{
Ivan Pepić \\ Institute for Social and Political Research \\ Mostar, Bosnia and Herzegovina \\ E-mail: ivan.pepic@idpi.ba
}

\author{
DOI: 10.20901/an.15.02 \\ Original scientific article \\ Accepted: November 2018
}

\begin{abstract}
This article discusses the political effects of two different conceptions of democracy in ethnically deeply divided societies. It considers the conflicts with clear historical roots by analysing the case of the Election Law of Bosnia and Herzegovina which involves two irreconcilable ideas of democracy expressed by the political elites of two communities, the Bosniaks and the Croats. The first part explains the conflict between Bosniak and Croat political elites, which have respectively, been trying to impose either the majoritarian or the consociational system since the 1990s. The second part discusses the decisions of the European Court of Human Rights and of the Constitutional Court of Bosnia and Herzegovina on electoral rules. It is argued that the imposition of integrationist-like rules and the suspension of consociational arrangements in the Election Law has increased divisions between the two ethnic communities. Finally, the article analyses the proposed amendments to election rules submitted to both state and entity parliaments, which confirm the existence of clearly irreconcilable visions of democracy within the Bosniak-Croat Federation.
\end{abstract}

Keywords Constitutional Court, election law, Bosniak-Croat Federation, concepts of democracy

\section{Introduction}

The design of election laws as part of electoral systems has notable political consequences for states and societies. Sartori (1968: 273) wrote that electoral systems are "the most specific manipulation instrument of politics" for a good reason. His famous words refer not only to political and interparty competition, but they can also be applied to deeply divided societies. In fact, discussions about election laws in deeply divided societies are often more than mere competition between political parties and groups. Questioning election laws in societies marked by deeply ethnic divisions means going deeper.

This questioning process seems to be happening to Bosnia and Herzegovina $(\mathrm{B}-\mathrm{H})$, a country composed of two asymmetrical territorial entities: the Serb-dominated Republika Srpska (RS) and the Bosniak-Croat Federation. ${ }^{1}$ The

\footnotetext{
For practical reasons, in this paper the Federation of B-H is defined as BosniakCroat. The definition is correct if we consider that the Federation is composed of 1.56 million (70.4\%) Bosniaks and 498,000 (22.4\%) Croats. Furthermore, until the
} 
political crisis that accompanies ethnic division between Bosniaks and Croats deepened following the event in which the Constitutional Court of B-H partially accepted on 6 December 2016 an appeal submitted by Božo Ljubić, as Chairman of the House of Representatives of the Parliamentary Assembly of $\mathrm{B}-\mathrm{H}$ and Croatian representative, in which he questioned the constitutionality of parts of Election Law. The Constitutional Court gave the Parliamentary Assembly six months to revise some of the obligatory rules of the Election Law. However, during this period, the Parliamentary Assembly failed to reach a consensus, which resulted in the Court's removal of the aforementioned contentious provisions on 1 December 2016. The provisions that required adjusting refer to the nomination of delegates of the three constituent peoples (Bosniaks, Croats and Serbs) and Others from cantonal assemblies to the House of Peoples of the Parliament of the Federation, an institution thought to represent constituent peoples and national minorities' interests. In fact, for many years, Croatian politicians have claimed that Bosniaks nominate an important number of their delegates to the Federation's House of Peoples. As the Constitutional Court ruled the provisions unconstitutional, not adhering to them could lead to a total deadlock. Although politicians have made some proposals for a new Election Law and its amendments, there are still some doubts on the legal implementation of the results of the general election that took place in October 2018.

beginning of 2000s, they were the only two constituent peoples that composed institutions based on ascriptive criteria. After the Federation of B-H's constitutional reform, which was imposed by the Office of the High Representative in 2000s, Serbs $(56,000$ or $2.5 \%)$ and Others (3.9\%) (FZS 2013) have also become constituent groups within the Federation.
The paper will mainly focus on the relations between Bosniaks and Croats within the Federation. These two constituent peoples are the largest group of the entity and have been afflicted by a crisis deeply rooted in political history. The Bosniak-Croat relation is certainly becoming one of the most tensed and destabilizing in the Balkans (Foreign Policy 2018, The Guardian 2018).

This article conceptualises and discusses the strong clash between the different understandings of democracy in societies that face changes in electoral rules. In this respect, the challenges affecting the Election Law and arising from a discrepancy in the points of view of Bosniak and Croat leaders could confirm that the liberal critics of consociation (beside the clash on understandings equality, as demonstrated by McCrudden and O'Leary 2013a, 2013b) have been arguing on two different understandings of democracy itself.

The article is based on secondary sources as well as on the following primary sources: newspaper articles published online, documents issued by domestic political parties, and international organisations. The article is divided into three parts.

In the first part, the article explains the struggles between Bosniak and Croat political elites for the imposition of respectively majoritarian or power-sharing system since 1990s. The second part of this paper discusses the decisions of the European Court of Human Rights (ECHR) in the cases Sejdic and Finci v. $B-H$ and Zornić v. B-H, as well as the Constitutional Court $\mathrm{B}-\mathrm{H}$ decision U-23/14 on the unconstitutionality of some articles of the Election Law. The root of the latter decision dates back to 2000 and 2002, when the international community imposed new electoral arrangements that substituted the conso- 
ciational model. The lack of key consociational arrangements in the Election Law increased divisions between the two ethnic communities. The article considers the Constitutional Court's decision as a step towards the return of consociation and the annulment of centripetal trends in B-H. The final part discusses the proposals of election rules submitted to both the Parliamentary Assembly of $\mathrm{B}-\mathrm{H}$ and the Parliament of the Federation of B-H, as proposed by Bosniak and Croat parties. It also briefly explains the proposals filed by domestic non-governmental organisations. The article proves its hypothesis that long-term polarization of the understanding of democracy has been one of the key causes of political divergence between the two ethnic communities in the Federation.

\section{A theoretical perspective: where does democracy come from in deeply divided societies}

In a normative discussion, O'Flynn (2010: 283) considers the relation between individuals and ethnic groups in ethnically deeply divided societies. He points out that "democracy requires governments to treat everyone with equal concern and respect, because ultimately that is what his or her moral standing demands". However, he adds that "in deeply divided societies, it is often claimed that groups, too, can be valuable in their own right". Most importantly, O'Flynn argues that individual and group rights are compatible and can be appeased.

Yet, at first glance, it is noticeable that the vision of democracy for "individuals" and "ethnic groups" differs. In order to appease these visions, which should reflect the interests of both individuals and ethnic groups, several theoretical approaches have been developed. In ethnically divided societies they try to permit all groups, including minorities, to be in- cluded in polity. These approaches could be classified in two major categories: centripetalism and consociationalism.

Centripetalism is an integrative approach that requires moderation from the political elite. It enables politicians who are ready to cross ethnic borders to be elected by all ethnic groups, and not only by the group whose candidate they are. Political institutions should be designed to avoid political extremism, which could offset negative characteristics that are present in deeply ethnically divided societies, such as discrimination and ethnic violence, as well as "pull politicians and their supporters towards a 'moderate middle"' (McCulloch 2013: 111). Centripetalism is also defined as a "strategy designed to focus competition at the moderate centre rather than the extremes" with three facilitating components: (1) the existence of electoral incentives for politicians to attract votes from ethnic groups other than their own; (2) the existence of multi-ethnic arenas of bargaining; (3) the development of centrist and multi-ethnic parties and coalitions that are "capable of making cross-ethnic appeals" (Reilly 2001: 11, 2012: 263). ${ }^{2}$ The approach suggests that "moderate political parties will find it easier to engage in cross-group cooperation" and reach political stability, just as it seeks to guarantee "both individual and group identities" in deeply divided societies (McCulloch 2013: 112). To do so, centripetalism favours political systems established on a combination of majoritarian and preferential rules that permit cross-ethnic elections based on Alternative Vote (AV) systems (Horowitz 1985; Reilly 2001: 264). ${ }^{3}$

\footnotetext{
Italics are Reilly's.

3 McCulloch (2013: 113) listed variations of the AV used in some countries, such it is the Limited Preferential Voting system (LPV) used in Papua New Guinea and Sri Lanka's Supplementary Vote (SV), all used in presidential elections.
} 
Critics of this approach exist among theoreticians and empiricists alike. Theoretically, consociational proponents "criticise integrationists for ignoring the reality of divisions on the ground and for exaggerating the basis for unity" (McGarry and O'Leary 2005: 675). Empirically, Fraenkel and Grofman (2006: 646) studied the case of Fiji and concluded that "Horowitz's theory failed to work as expected in Fiji owing to several inherent flaws". On the other hand, McCulloch (2013: 113) regrouped 24 states in which elections were held and then argued that "only four achieved the anticipated centripetal result of moderation and greater stability". Similarly, attempts by the international community to switch from consociation to certain centripetal elements in $\mathrm{B}-\mathrm{H}$, in particular the ones based on cross-ethnic votes and moderation, have been producing divisions between ethnic communities (Pepić and Kasapović 2017).

Consociation is an approach attributed to Lijphart $(1969,1977)$. This approach assumes a presence of a deeply segmented society whose elites decide to cooperate in order to maintain stability. Four basic principles are characteristic of consociation. First, a grand coalition composed of representatives of all significant segments. They participate in decision-making process and represent their segments. Second, veto is another key element that prevents possible outvoting for the protection of minority segments' vital interests. Third, proportionality is used as an objective tool for resource allocation and representation in common institutions. Finally, segmental autonomy, often accompanied by federal elements (Lijphart 1979), allowing distinguished policies and independent decisions on the interests of specific groups.

Originally, consociation has been thought to accommodate groups on the basis of "predetermined" criteria. These criteria define the "corporate" form of consociation which is based on ascriptive criteria (ethnicity, national group, religion, etc.) assuming that "group identities are fixed and that groups are both internally homogeneous and externally bounded" (McGarry and O'Leary 2005: 675). A predetermined or corporate consociation "privileges such identities at the expense of those group identities that are not accommodated" and that go beyond predetermined identities (McGarry and O'Leary 200\%. 675). On the other hand, "self-determined" criteria forms the liberal consociation which allows "groups to manifest themselves instead of deciding in advance on the identity of the groups" (Lijphart 1995: 275). According to McGarry and O'Leary (2006: 675-676) self-determination also takes care "to ensure that the rights of individuals as well as groups are protected".

Considering these arguments, O'Flynn (2010: 286-287) favours self-determination against predetermination, arguing that it is more "flexible" and suitable "for future changes", and that it "leaves people free to decide for themselves". Nevertheless, some clarifications about the theoretical and empirical borders between centripetalism and self-determined consociation might be necessary in the future. ${ }^{4}$ Are O'Flynn's arguments on the flexibility of self-determined consociation always valid or could they be a tool for integrationist theorists and policy-makers? What happens when it comes to practical challenges that rely upon a clear ethnic split creating two different politics of 'understanding democracy?'

\footnotetext{
4 Indeed, some empirical cases, mainly regarding $\mathrm{B}-\mathrm{H}$, show that "liberal consociation leads to the degradation of consociation in general, which raises the question if liberal consociation can survive" (Pepić and Kasapović: 2018: 9).
} 
Assuming that $\mathrm{B}-\mathrm{H}$ has passed from corporate to liberal consociation, with clear centripetal tendencies, these theoretical reflections are a tool for a better understanding of the study that tries to confirm these processes and theoretical assumptions.

\section{The roots: Bosniak-Croat relations in 1990s, the OHR and moderate governments}

On 1 December 2016 the Constitutional Court annulled several parts of the Election Law of $\mathrm{B}-\mathrm{H}$ concerning the election of delegates to the House of Peoples of the federal parliament. After that, the political crisis between Bosniaks and Croats deepened. The representatives of the two peoples have been proposing asymmetrical solutions to the Court judgement ever since. Nevertheless, this crisis could be described as persistent since the 1990s. Indeed, the different visions of the political system of B-H led to war between Bosniaks and Croats. Since then, Bosniak leadership have tried to forcibly stop any attempt of power-sharing, while Croat political leaders, on the contrary, have been trying to promote and preserve it.

\section{Bosniak-Croat struggles in the 1990s}

Before the devastating 1992-1995 war, the population census results in 1991 recorded that the three largest ethnic groups were the Bosniaks 5 (1.9 million, $44 \%$ of all), the Serbs (1.4 million, $31 \%$ ) and the Croats $(760,000,17 \%)$. All others $(350,000,8 \%)^{6}$ were the remaining ethnicities or unaffiliated individuals (Tabeau and Bijak 2005: 188). Only two of the three ethnic groups, the Bosniaks and the Croats, expressed their will to vote in favour of B-H independence at

5 Known as Muslims until 1994 (Hayden 2005: 229).

6 Hayden (2005: 235) defines them "Yugoslavs and others". the 1992 referendum, while the Serbs opted to abstain, thus showing their desire to remain in Yugoslavia. However, the Bosniaks and the Croats, due to their very different population proportions, have persistently had a different view of B-H political system (Hayden 2005: 238-241).

Before the total escalation of the war in February 1992, the European Community (EC) proposed a 'Statement on the principles of a new constitutional solution for B-H', also known as Cutileiro plan. The plan sought to define B-H as a country of "three constitutive units defined primarily by ethnic principles", which consisted of non-contiguous cantons (Burg and Shoup 1999: 110-111). The Cutileiro plan confirmed that B-H "would have all the attributes of a single state, including its own currency, a single system of defence, a single foreign policy, and a single legal-judicial system" (111). Despite the fact that at the beginning all three sides agreed, the Bosniak leader Alija Izetbegović refused to sign due to at least two reasons: first, he openly stated that he was against the "ethnic division of Bosnia", and second, because he was aware that the United States (U.S.) would push through the recognition of his government, which would enable him gain power through a more centralistic B-H political system (Burg and Shoup 1999: 113-115). On the other hand, Croat leaders accepted this "'consociational' proposal" (Harland 2017: 9) because it permitted facilitating relations with Croatia and provided great autonomy for Croat-majority areas. This was in a serious disagreement with the vision of B-H political system and it "fuelled the conflict between Bosniaks and Croats" (Keil 2012: 211).

Initially, Bosniak and Croat leaders sought to establish both a defence and political coalition against the Serbs, who were at the time perceived as mutual en- 
emy and aggressor. While Croatia experienced the war first, the "Bosnian Muslim community generally lagged behind the Bosnian Croat community in the creation of defence forces" (Shrader 2003: 32). On 22 July 1992 the Croatian President Franjo Tuđman and the Chairman of the tripartite Presidency of B-H Alija Izetbegović signed the "Agreement on Friendship and Cooperation between Bosnia and Herzegovina and Croatia". Signing the 1992 Agreement on Friendship, the Bosniaks and the Croats agreed on both military and political power-sharing. Three significant elements were decided: first, as the main Croat civil and military organisation in $\mathrm{B}-\mathrm{H}$, the Croatian Defence Council (HVO), was a component of common $\mathrm{B}-\mathrm{H}$ forces "having its representatives in a joint command of the armed forces of Bosnia and Herzegovina". Second, that the "future state system of Bosnia and Herzegovina will proceed from the principle of full equality of three constituent nations: Muslims, Croats and Serbs". Finally, it was decided that the "constitutional-political system of the country will be based on constituent units in the establishment of which due account will be taken of national, historical, cultural, economic, traffic and other elements" (Agreement on Friendship 1992, quoted in: Trifunovska 1994: 656-657). ${ }^{7}$

Some authors interpret the 1992 Agreement on Friendship as a confirmation of Croatia agreeing to the HVO being under the command of Armed forces of $\mathrm{B}-\mathrm{H}$, or even the Bosnian Territorial Defence Force, which became the Bosniak-majority Armija BiH (see Hoare 1997; Ramet 2006). For example, Hoare (1997) writes that "on 21 July 1992 Tudjman signed a military pact with Izetbegovic in which the HVO was placed under the command of the Bosnian TO (Territorial Defence)". This is simply untrue. The fact is that the Agreement of Friendship was signed on 21 July 1992 believing it would be a joint HVO-Armija commando (Agreement on Friendship, quoted in: Agreement on Friendship 1992, quoted in: Trifunovska
Contrary to agreed military and political power-sharing, on 6 August 1992 Bosniak leaders unilaterally signed the "Legislative Decree on Amendments to the Decree on Armed Forces of the Republic of Bosnia and Herzegovina" which was opposed to the 1992 Agreement on Friendship signed several weeks

1994: 656-658; Shrader 2003: 66), which was unacceptable for Bosniak leaders who would accept neither military nor political power-sharing, as they had the majority of the population and sought to preserve political power. Indeed, only a few weeks later, on 6 August 1992 Izetbegović signed the "Legislative Decree on Amendments to the Decree on Armed Forces of the Republic of Bosnia and Herzegovina" that de facto annulled the Agreement on Friendship placing HVO under a unique Armija's command. Furthermore, it should be taken into consideration, as noted in Burg and Shoup's (1999: 229-230) description of the Vance-Owen Plan, that "Croats sought to resolve the issue of military deployments under the Vance-Owen Plan by proposing that all military units in the provinces designated as Croat-majority provinces be placed under the control of the Bosnian Croat army (HVO) provincial command structures. They also sought that these be unified under a single $\mathrm{HVO}$ command for all Croat majority provinces. A parallel arrangement would have been established in Muslim-majority provinces", while on the state level HVO and Armija should have had a "joint command". On the other hand, "Muslims insisted that only a single unified command for all of Bosnia-Herzegovina be established above the level of the provinces" (Burg and Shoup 1999: 229-230). This different vision of armed forces' organisation in deeply divided societies is nothing new: for example, in 1963 Makarios' Thirteen Amendments prescribed a complete unification of Greek and Turkish Cypriot military commands and headquarters, including a "complete integration of the two ethnic communities at all levels of the military hierarchy", which was perceived very negatively by the Turkish Cypriot minority that protested against the unilateral decision implemented by the Greek majority, because this led towards a possible exclusion of Turkish soldiers (Adams 1966: 485). Cyprus has been divided since 1974. 
earlier. In fact, instead of the principle of equality in the commando, the Legislative Decree recognised the $\mathrm{HVO}$ as a component of Armija BiH, but $\mathrm{HVO}$ was "placed under a unique command of the Armija BiH" (Legislative Decree 1992, quoted in: Šiber 2000: 306-307). This decision had clear repercussions on common civil and military organisations. For instance, in the second part of 1992, Bosniak local representatives obstructed HVO civil and military structures, while some were openly blamed by Bosniak leaders for opposing the separation from HVO (Shrader 2003: 66; Marijan 2006: 386).

Bosniak leaders did not accept political power-sharing between Bosniak and Croat organisations, whereas the Croats insisted on it. This also included territorial subdivision on clear ethnically-based regions (Keil 2012). Their mistrust was influenced by different factors that could be summed up reading certain authors' interpretations. Firstly, Malcom (1994: 240) states that Izetbegović was reluctant to cooperate with Croats because "he feared an eventual absorption of Bosnia into a Greater Croatia". Friedman (2004: 123) thinks that, contrary to B-H Serbs and Croats, the "Bosnian Muslims were the only group in Bosnia that publicly stated a desire for a united Bosnia", although certain Croat authors claim that the Croats were also for a united B-H, but highly decentralised, while the Serbs sought to be part of a unique Serbian state (see e.g. Lučić 2013; Arlović 2017). Secondly, certain authors argue that, paradoxically, the belated "official recognition of the Bosnian Muslims made them vulnerable to Serb and Croat pressures, because neither group would accept the Bosnian Muslims as anything more than a religious entity - certainly not as a national entity" (Friedman 1996: 1). These geopolitical views were further boosted by meetings between Tuđman and Serb leader Slobodan Milošević in the spring of 1991, which were interpreted by some journalists and scholars as secret meetings for the partition of Bosnia (Malcolm 1994: 232-233; Friedman 1996, 2004; Murdy, 1999: 342). In fact, some Bosniak leaders and intellectuals perceived Croatia and Serbia as opportunists and worried that "like their interwar predecessors Maček and Cvetković in 1939, Tudjman and Milošević conspired together in the turmoil to carve up Bosnia and Herzegovina without Muslim input" (Friedman 1996: 214). Consequently, power-sharing had generally been perceived and described by Bosniak leaders as a mechanism that threatens the country's integrity and puts their identity at risk, while the Croats characterised it as system which would permit them to preserve political autonomy and equality being the less numerous constituent people in $\mathrm{B}-\mathrm{H}$.

The general perception about Serb and Croat aspiration for partitioning $\mathrm{B}-\mathrm{H}$, which was also perceived as a threat for the affirmation of the Bosniak identity, and the presence of Bosniak refugees in Central Bosnia and Northern Herzegovina demographically pressurizing Croatian-majority municipalities (Shrader 2003: 3-4, 13) combined with the political polarization between the two groups resulted in war and in up to now irreconcilable political tensions between Bosniaks and Croats.

From the Washington Agreement to the OHR's centripetal impositions

The 1992-1994 Bosniak-Croat War ended after the two sides signed the U.S.-sponsored 1994 Washington Agreement that formed the Bosniak-Croat Federation as a partial state based on prototypical corporate consociational arrangements (Belloni 2007: 3; Pepić and Kasapović 2018: 7-8). This 
agreement preceded joint Bosniak-Croat military offensives, which led to the 1995 Dayton Agreement and the end of war in B-H (Burg and Shoup 1999: 346-347). The Dayton Agreement also set up the Office of the High Representative (OHR), an international institution that reports to the United Nations Security Council. The OHR gradually became one of the most important state-building international institutions in B-H. Indeed, the OHR was only a "civilian advisory" international institution. In 1997, at the Peace Implementation Conference in Bonn the OHR was given executive (Bonn) powers which permit the High representative to implement constitutional laws, decisions, acts, and appoint or dismiss officials, without legislators approving of such decisions (Van Willigen 2010).

The 1994 Washington Agreement enabled the creation of 10 cantons, prescribed the structure of government as well as the division of responsibilities between the central government, cantonal and municipal authorities. Moreover, signing the Washington Agreement, the Bosniaks and the Croats also accepted the Constitution of the Federation. The power-sharing system was the key condition for appointing executives and legislatures. According to the Washington Agreement (1994), the legislature is defined as follows:

"1. Legislature shall consist of two houses:

a. The House of Representatives, which shall be elected democratically on a proportional basis in the Federation as a whole;

b. The House of Peoples, which shall have an equal number of Bosniak and Croat delegates. Each canton shall be allocated a number of seats to be occupied by Bosniak delegates and a number of seats to be occupied by Croat delegates, in proportion to these two groups in the Legislature of that canton, the Bosniak and Croat delegates from each canton are to be elected, respectively, by the Bosniak and Croat representatives in its Legislature".

Until 2000, electoral rules were compatible with consociational mechanisms of the Federation's Constitution based on the Washington Agreement that defined its legislature. Despite this, the OHR ignored the functionality of consociational arrangements for the election of the federal House of Peoples and opted for a centripetal model, including inter-ethnic accommodation, integrationist policies, and open support given to moderate coalitions. In 2000, intra-ethnic voting prescribed by the Washington Agreement was substituted by inter-ethnic voting so that "everybody voted for everybody" (Kasapović 2016: 178; Bose 2002). Or, as described by McCrudden and O'Leary (2013b: 73), "almost immediately after the ink had dried on the Agreement, 'the international community began pushing for reforms' that sought to move the Bosnian arrangements from being consociational to integrationist in nature".

For a long time, the leading B-H Croat political leaders stressed that the new rules have nothing to do with the original version of the Washington Agreement, mainly because "Bosniak cantonal legislators, who make up the majority of members of the ten cantonal assemblies, would heavily influence the election of Croat members of the House" (Kasapović 2016: 178), and consequently, it had an impact on the formation of executives. On the other hand, integrationist behaviour of Bosniak politicians, who supported the amendments of the Washington Agreement, is often explained through the argument of a potential "Poland-like scenario" in which 
Croatia and Serbia would play the roles of Germany and Russia (Belloni 2007: 43). In order to avoid this scenario, "Muslims have tended to be supportive of international efforts to reintegrate the country", which also meant supporting integrationist parties (Hoare 2007: 408).

The visible switch from classic consociational, as defined by the 1994 Washington Agreement, to centripetal-like rules following OHR impositions in 2000s, can easily be traced by considering two major changes that affected the nomination of delegates in the Federation's House of Peoples.

First, the Washington Agreement prescribed that "Bosniak and Croat delegates from each canton are to be elected, respectively, by the Bosniak and Croat representatives in its Legislature". However, after OHR's intervention in 2000 this fundamentally changed and it was allowed voting for delegates who were not from the same ethnic group. New rule proposed by the OSCE Ambassador Robert Barry (consequently known as the "Barry's Amendments") regulated the election of members to the Federation's House of Peoples and "decreed that all members vote for all candidates, so that Croats would vote for Bosniak representatives and vice versa" (Belloni 2004: 344).

Second, "Barry's Amendments" were valid for the election in 2000, but since then some other constitutional amendments have been imposed. The 1994 Washington Agreement stated that "each canton shall be allocated a number of seats to be occupied by Bosniak delegates and a number of seats to be occupied by Croat delegates, in proportion to these two groups in the Legislature of that canton", and the first Constitution of the Federation prescribes that "there shall be at least one Bosniak, one Croat, and one Other Delegate from each Can- ton that has at least one such member in its Legislature". Interestingly, after following through the OHR's constitutional amendments, ${ }^{8}$ the number of delegates diminished from 30 for Bosniaks and Croats to 17 for each of B-H's three constituent peoples and seven for Others. These changes had a great impact on the nomination of the Government of the Federation and the President and Vice-Presidents of the Federation, mainly because the less numerous constituent peoples and Others have had minor possibilities to influence the election of these executive bodies. Indeed, the way in which the executive is elected has also changed, diminishing the possibility for Croats, Serbs and Others that took part in the decision-making process after 2000, to influence the appointment of the executive and to use the veto as one of four principles of consociation when appointing members to the government (cf. Bennett 2016: 220-222).

\section{The moderate governments}

After the war, the international community started to question the integrity of the B-H political system. They were aware of the impossibility of building a functional state with a common institution. As concluded at the Bonn Peace Implementation Conference on 10 December 1997, one of the main problems was the "lack of strong multi-ethnic political parties and a structured civil society" that would influence the Peace Implementation Council - an international body composed of main powers such as Canada, the European Commission, Russia, Turkey and the U.S. that advises the OHR - to recognise "the need to support the establishment of new multi-ethnic parties and to strengthen the existing ones" (OHR 1997). The

\footnotetext{
8 From 1994 to 2005, 108 amendments were adopted to the Constitution of the Federation of B-H (Vukoja 2013: 97).
} 
OHR were also given executive powers because they supported multi-ethnic parties and coalitions, which were implemented through electoral engineering at the beginning of the 2000s.

In 2000, the international community introduced electoral rules in $\mathrm{B}-\mathrm{H}$ based on "Horowitz's key conditions for preferential social choice functions to produce cross-cleavage results" (Bunta 2018: 105). ${ }^{9}$ In RS, an alternative voting system was introduced in order to launch multi-ethnic coalitions, accommodation and centrist politics, which relied on ethnic and nationalist parties instead of disintegration. Similarly, in the Federation, the electoral rule changes based on Horowitz's key conditions for the election of delegates to the House of Peoples comprised cross-ethnic voting. These rules have permitted the Bosniak members that have the majority of representatives in cantonal assemblies to nominate delegates of Croats as minor constituent people. ${ }^{10}$

The imposed electoral regulation amendments caused serious suspicion among Croat political leaders. Among the constituent peoples, the choice of supporting cross-ethnic coalition alongside the winners has consistently caused suspicion even amid certain foreign authors. Bose (2002: 235) points out

9 The main theorist of centripetalism, Donald Horowitz, confessed to Florian Bieber (2006: 148) that he was consulted by international institutions in $\mathrm{B}-\mathrm{H}$. Some electoral reforms were also introduced after consultation with Benjamin Reilly in Sarajevo, a promoter of Horowitz's approach (Arnautović 2009: 599; see in: Kasapović 2016: 178).

10 The article IV.A.2.8(1) of the Constitution of the Federation of B-H (2011) prescribes that "Delegates to the House of Peoples shall be elected by the Cantonal Assemblies from among their representatives in proportion to the ethnic structure of the population". So delegates to the House of Peoples are selected from among representatives in the cantonal assemblies. that B-H's population is not heterogeneous enough for elections based on cross-ethnic methods. Similarly, Belloni (2004: 345) writes that "the 2000 election demonstrated that, while the international community had shown an increasing interest in promoting moderate politicians, the ad hoc approach made intervention prone to failure".

Since Bosniak leadership knew it had "numbers on its side" (Bennett 2016: 257), the decision made in 2000 has had repercussion mainly for the Croats in B-H. The Croat political elite was "in the weakest position and Croats are generally most disenchanted with the peace process" which was also influenced by their "dwindling proportion" in $\mathrm{BiH}$ (Bennett 2016: 257). Even influential international actors, who have traditionally been against the interests of Croat leadership, often considered nationalistic, recognised how changes in electoral regulations "have evoked genuine concern by Croats that they risk being marginalised in a state where Bosniaks and Serbs enjoy special advantages" (ICG 1999: 53). Furthermore, Croat leadership protested at least twice following Croats' marginalization after electoral regulations were changed and engineered by the OHR.

Firstly, before the 2000 general election, the international community isolated national parties by imposing "Barry's Amendments" and promoting the ten-party "Alliance for Change" coalition government (Hoare 2007: 408). Although the Croatian Democratic Union of $\mathrm{B}-\mathrm{H}$ (HDZ) won $17.5 \%$, the majority of Croat votes within the Federation, seats reserved for Croat members in the Government of the Federation were filled by members who won less than 2\% (Manning 2004: 67). HDZ and its partners decided to create the Croat National Assembly (Hrvatski narodni sabor, HNS), a "transitional structure 
that would operate as the Croat self-governing body" (Belloni 2007: 55). HNS withdrew from federal institutions and declared the Croat Self-Government by establishing a Croat-majority inter-cantonal and inter-municipal council (Bieber 2001). However, the international community forced the Croats to annul this decision and to reintegrate into the Federation. After HDZ's rebellion and tensions, trust between the international community and Croat leaders was broken (Belloni 2004: 344).

Secondly, after the 2010 general election, the OHR made a decision that, again, was not in sync with consociational principles. Again, the OHR supported moderate parties, regardless of their results. The OHR annulled the election results and the decision of the B-H Electoral Commission by imposing the "Platforma" coalition which included the Social Democratic Party (SDP), the Party of Democratic Action (SDA), the People's Party Work for Betterment (NSRzB) and, paradoxically, the pro-ustasha far-right Croatian Party of Rights (HSP BiH). ${ }^{11}$ Similarly to 2000, the "Platforma" coalition excluded HDZ even though the party won the majority of votes among the Croats (Central Election Commission 2010). Conse-

11 The Hrvatska stranka prava BiH (HSP BiH) is a far-right party whose ideological roots could be found in the 1941-1945 ustasha regime. After the first democratic election in 1990s, the HSP formed a paramilitary arm of the Croatian Defence Forces (HOS) which tried to annex $\mathrm{B}-\mathrm{H}$ and re-create Croatian borders as they were during the Independent State of Croatia (NDH). Paradoxically, SDP is a party that underlines its anti-fascist roots, but it accepted to make a coalition with HSP. Finally, in 2010, SDP led by Zlatko Lagumdžija met the coalition members in HSP's headquarters in Mostar. During the meeting, a bust of the ustasha leader Ante Pavelić was present alongside the main guest, which did not cause any complaints among Bosnian social-democrats (Faktor.ba 2017). quently, HDZ initiated the revival of the HNS, this time as a party coalition that organised both political and non-governmental affairs. The HNS did not quit the Federation's institutions; instead, its main members pursued a legal action before the Constitutional Court to tackle the Election Law. As pointed out by Zdeb (2016: 559), this time the HNS was an "extra-constitutional representative institution" that started a "subtle long-lasting fight for equality of Croats in Bosnia, which also implied future constitutional change".

On the Bosniak political scene, new rules created serious tensions in the year 2000. The Bosniak scene was composed of some right- and left-wing parties. The first had been traditionally devoted to national identity building, often based on religious traditions, while the latter had often been defined as "multi-ethnic" or "civic". In fact, the SDA is a conservative and the most important right-wing Bosniak party. On the other hand, the civic bloc was composed of parties which inherited either liberal or social-democratic traditions. The most influential party is the reformed Communist Party, the SDP, which tries to keep links to Titoism and cross-ethnic appeals, although "this party predominantly attracts Bosniak voters" (Caspersen 2004: 575; Bieber 2006: 105). Following post-electoral pro-moderate engineering by the OHR in 2000, however, the SDA won the election among the Bosniak population. The party was excluded from the formation of the "Alliance for Change" coalition government (Manning 2004; Hoare 2007: 408). Since then, a strong ideological and political polarization among the Bosniak political arena has persisted, including different views towards the existence of entities and constituent peoples. While the conservative Bosniaks seek to preserve the status quo and cooperate with Croat 
and Serb winning parties within common institutions, the civic bloc calls for cross-ethnic cooperation and diminution of entities powers or even for their abolition (see Bose 2005). ${ }^{12}$

Contrary to the Croats, who have consistently voted for the HDZ, in 2000 the Bosniaks were very largely represented by the SDP, which won 26 percent of seats in the Federation's lower House of Representatives (Central Election Commission 2000). Moreover, contrary to the Croats who have been "the smallest group, and they do not have the institutional protection offered by their own entity", which probably explains why their politicians pushed for the Croat Self-Government, the SDA proclaimed "itself to be 'a national/people's party of the political centre open for all citizens of Bosnia and Herzegovina'" (party's final declaration at the Third SDA Congress, quoted in Caspersen 2004: 576). This position can be interpreted as trying to become more politically acceptable to the international community in times when nationalist policies were sanctioned by the OHR.

Following the 2010 election, the SDA decided to accept to become part of the "Platforma" coalition government

12 Tensions between the conservative and civic Bosniak bloc have persisted mainly due to ideological issues. For instance, Sarajevo's social-democrats tried to abolish the religion-course in schools, which resulted in a fierce political reaction by the conservative forces (Pogled.ba 2011). However, as it will be argued further in the article, since the ECHR and the 2016 Constitutional Court decisions, these Bosniak blocs have developed common strategies and have been acting as a mono-ethnic coalition against all proposals made by Croatian parties. Furthermore, as it will be argued later, since then these parties have supported each other with common proposals for the Election Law reform based mainly on cross-ethnic voting models, mainly concerning the representation of constituent peoples. together with the civic parties and the HSP. This action was negatively perceived by the HNS coalition, which saw the coalition as a Bosniak bloc against the Croat community.

\section{ECHR and Constitutional Court judgments on electoral rules}

Electoral rules in $\mathrm{B}-\mathrm{H}$ have been contested for decades by all ethnic groups and minority members. It is possible to distinguish two opposed groups and types of contestations: (1) minority groups, which contested the impossibility of running for the tripartite Presidency of B-H, and (2) constituent peoples, which contested the majoritarian rules that exists for the election of certain institutions initially thought to be based on consociational arrangements.

\section{Minority groups and electoral rules: the Sejdić-Finci v. B-H and Zornić v. B-H cases}

Members of the Roma and the Jewish communities, Dervo Sejdić and Jakob Finci, expressed concerns about the impossibility of running for tripartite Presidency and the upper chamber of the state parliament (the House of Peoples), reserved only for members of the three main ethnic groups (Bosniaks, Croats and Serbs) according to the Election Law. The lawsuit was rejected by domestic courts. Although one could argue that "political discrimination suffered by Others is very limited, especially when considered in the context of preserving the stability of democratic institutions and peace among the significant segments of Bosnian society" (Stojanović 2018: 350), the ECHR accepted it and in 2009 they issued a sentence that has obliged B-H to reform their political institutions and permit to non-members of the three ethnic groups to be appointed and elected in all B-H institutions. 
The same happened to Azra Zornić, a Bosnian citizen who claimed she was discriminated against because the electoral rules obliged her to plead as a member of one of three constituent peoples in order to run for election to the House of Peoples. Zornić insisted on declaring herself as a Bosnian citizen, without affiliating to any constituent people. The ECHR's verdict in 2014 was the same as in the Sejdić-Finci verdict (ECHR 2014).

The two decisions by the ECHR challenged consociation both in practice and theory. Considering the practical aspect, the Sejdić-Finci judgment has become an explicit bureaucratic requirement for the path towards the European Union (EU). The ECHR asked B-H politicians to amend the constitution according to the Sejdić-Finci judgment, which has also become an EU request (Milanović 2010: 640-641). However, this judgment remains unimplemented. Furthermore, McCrudden and O'Leary (2013a: 496, 2013b: 130-131) argue that the apparent "civic model" decided by the ECHR "is not neutral", since it "took sides in favour of the Bosniak position and against the Bosnian Croats and (particularly) the Bosnian Serbs". In fact, by trying to limit power-sharing since 1990s, Bosniak leaders have called for "a more integrated country along the lines of 'one man, one vote' principle" (Belloni 2007: 55) and tried to implement the ECHR's judgment by using this formula. Besides, the Sejdic-Finci verdict that favours a liberal vision of human rights over consociational norms (McCrudden and O'Leary 2013b) goes hand in hand with Bose's descriptions of "some sectarian Bosniak political figures who want to appear 'liberal' to Westerners - distinguishing them both from ethno-nationalists in their own group and from the incorrigibly nationalist 'enemy' group(s)" (2005: 325). It is clear that after the war more and more actors have expressed a tendency to undermine and even blame consociational arrangements, not only in B-H, but at the international level where many theorists and policy-makers state that consociation is undemocratic (cf. Lijphart 2018: 9).

Theoretically, the ECHR's decisions fit in what McCrudden and O'Leary (2013a: 483) describe as "two different understandings of equality" when consociation is put under pressure by an "individualised and majoritarian conception of equality" although it seeks to further "equality between the consociated peoples or groups". A second, less studied impact on consociational theory concerns different understandings of democracy. In fact, interpreters of democracy's definitions have become "exclusivists" and prompted to clashes, which dissolves consociation's theoretical relevance and increases integrationist approaches. Explaining the ECHR's judgments, theorists ignore and undermine consociation as a democratic approach. While Lijphart (2018: 9) defends consociation arguing that "there is nothing undemocratic about consociationalism", Stojanović (2018: 350) points to the ECHR's judgment stating that it "might have consequences for other consociational regimes as well". Wheatley (2012: 173) suggests that the ECHR finds that "discrimination in the enjoyment of political rights on grounds of race or ethnicity could not be justified in any circumstances: the political equality of citizens is a 'constitutional prerogative' in democratic states". The construction of an "archetypal democratic state" based on individuals' equality presumes the exclusion of power-sharing, because it focuses exclusively on individuals, not on (ethnic) groups (Wheatley 2012: 172). This way, the ECHR has posed a threat to the idea of consociation as a legitimate tool for reconciling divided societies, which tries to strengthen de- 
mocracy and at the same time preserve the segments' equal representation.

Paradoxically, certain authors argue that the ECHR's judgments reopened the "Croat question". Efendić (2013) observes that "Bosnia Solves 'Croat Question' at Sejdic-Finci's Expense" since international actors became aware of the problem that on some occasions the Croats were outvoted. According to Bunta (2018: 141), after the imposition of the centrist government in 2000, "Croats advocated that there was a hole in the Dayton agreement when it came to the implementation of consociational theory via segmental autonomy. The Croat elites do not have a problem with consociational theory itself; rather, they believe their autonomy is not safeguarded like the Serbs and Bosniaks". He argues that "the Croat elite took advantage of the European audience eager to hear propositions for reform" and have found a "loophole" in the Sejdić-Finci logic, which pushed them to appeal to the Constitutional Court complaining that the electoral mechanism for the election of the federal House of Peoples violates the state's constitution (Bunta 2018: 144-146).

\section{Constitutional Court judgment: "The principle of legitimate democratic representation"}

After the decisions on "individual rights" made by the ECHR, the Constitutional Court took a decision in favour of constituent peoples, the decision U-23/14.

The most recent Court decision is related to the House of Peoples of the Federation's bicameral parliament. The House of Peoples is composed of 54 members: 17 Bosniak delegates, 17 Croat delegates, 17 Serb delegates and seven delegates that represent the "Others". The aforementioned delegates are appointed by the representatives of 10 Federation's unicameral cantonal as- semblies. Each cantonal assembly has the right to appoint a number of delegates as defined by the Election Law.

In 2014, Božo Ljubić, as Chairman of the House of Representatives of the Parliamentary Assembly of B-H and HNS representative, requested the revision of the constitutionality of the Election Law. On 1 December 2016, the Constitutional Court adopted decision number U-23/14, establishing the unconstitutionality of rules on the election of members of the upper house of the Bosniak-Croat Federation's Parliament, the House of Peoples. The Constitutional Court declared parts of Article 10.12(2) ("all constituent peoples are given one mandate in each canton") and Article 20.16.A (a-j) (which prescribe the number of delegates for each constituent people and Others from all the cantons) as non-compliant to Article I(2) of the Constitution of B-H on democratic principles (Constitutional Court of B-H 2016, Election Law 2018).

The two articles of the controversial law are directly linked to the OHR's intervention in the early 2000s. Namely, they were related to the 2001/02 rule of decreasing the number of House of Peoples' delegates from 30 to 17 for Bosniaks and Croats. ${ }^{13}$ This rule substituted the centripetal decision, the "Barry's Amendments" valid in 2000 based on cross-ethnic voting method, that permitted all cantonal assemblies' members to vote for the appointment of delegates to the House of Peoples - independently of their ethnic affiliation.

In fact, by diminishing the number of delegates from 30 to 17 , members of the smallest constituent people suffered since their veto rights depended on delegates appointed by one ethnic

${ }^{13}$ In 2002 it was given the possibility to 17 delegates for Serbs and seven for Others. Before, according to the Federation's constitution, these two groups until 2002 had not be permitted to appoint delegates. 
Table 1. Number of delegates in the Bosniaks', Croats', Serbs' and Others' Clubs (caucuses) in the Federation's Parliament elected from cantons with Bosniak or Croat majority and from mixed population cantons (Vukoja 2013: 99) ${ }^{14}$

\begin{tabular}{lccccc}
\multicolumn{1}{c}{ Cantons } & Bosniaks & Croats & Serbs & Others & Total \\
$\begin{array}{l}\text { Cantons with Bosniak } \\
\text { majority }\end{array}$ & 12 & 6 & 12 & 5 & 35 \\
$\begin{array}{l}\text { Cantons with Croat } \\
\text { majority }\end{array}$ & 3 & 5 & 3 & 0 & 11 \\
Mixed cantons & 2 & 6 & 2 & 2 & 12 \\
\hline Total: & 17 & 17 & 17 & 7 & 58 \\
\hline
\end{tabular}

majority from cantonal assemblies. This leads to a situation where the less numerous groups sometimes have not a single elected representative. Moreover, less numerous constituent peoples and Others have been denied the possibility of legitimately influencing the appointment of the executive. According to the Election Law, in order to be elected to the House of Peoples, delegates can declare themselves as members of a certain community even if up to then they were members of other ethnic communities.

For instance, there are two dozen Croats in the Bosnian-Podrinje Canton Goražde (FZS 2013). According to the law, seats in the House of Peoples of the Federation's Parliament had to

14 This table is based on the summation of the number of delegates for each constituent people according to the Election Law article 20.16.A (a-j) annulled by the Constitutional Court in 2016. For instance, from five cantons with Bosniak majority six Croat delegates are elected. The Election Law prescribed how many delegates for each constituent people and Others are elected from each canton (17 Bosniaks, 17 Croats, 17 Serbs and seven Others). However, if for instance we sum the number of Croats from majority Bosniak cantons, there are from Una-Sana Canton one Croat, Tuzla one, Zenica-Doboj two, Bosnian-Podrinje Goražde one and Sarajevo one (Election Law 2018). So in total there are six of 17 Croats that are elected from Bosniak-majority cantonal assemblies. be filled so that at least one mandate is awarded to each constituent people. The absurd situation happened when the Bosniak-majority Bosnian-Podrinje cantonal assembly appointed an ethnic Bosniak who simply declared himself as a Croat delegate in order to be recruited to the Croat caucus in the House of Peoples. ${ }^{15}$

Discrimination affects all constituent peoples and Others when it comes to the appointment of delegates to the House of Peoples from cantons where they are a less numerous group. Vukoja

15 This was the case of Edim Fejzić (Diaspora Party), an ethnic Bosniak and former soldier of the Armija $\mathrm{BiH}$, who was appointed as a Croat delegate (2014-2018). In the 2014 election, his party won 677 votes in a canton inhabited by 24 Croats. Interestingly, the Bosnian-Podrinje Assembly tried to appoint Muamer Omanović (SBB) as a Croat delegate, but he has often changed his "affiliation", sometimes declaring himself as Bosniak and other times as Croat. The same happened when the Una-Sana Canton appointed Mirvet Beganović, who fought the war as member of Fikret Abdić's paramilitary "People's Army". Beganović is the president of the assembly of the Association of Prisoners Western Bosnia, who have declared that they were tortured by the Armija $\mathrm{BiH}$. The same applies to Serb delegates from cantons with a Bosniak or Croat majority, but also for Bosniak delegates elected in certain Croat-majority cantonal assemblies (N1 2016). 
(2013: 99) argues that the appointment of delegates to the House of Peoples of the Federation's Parliament depends on the number of delegates appointed from Bosniak, Croat or mixed cantons. Being the majority, Bosniaks obviously influence the elections of Croat, Serb and Others' delegates. Similarly, Croats could elect Bosniaks in Croat-majority cantons, but the impact would be minor, as elected Bosniaks from Croat cantonal assemblies are not very numerous compared to non-Bosniak delegates elected from Bosniak-majority cantons.

Indeed, 35 delegates have been elected from the Bosniak-majority cantonal assemblies, 11 from Croat-majority cantons and 12 from mixed cantons. Each of the three constituent peoples has 17 delegates selected from ten cantonal assemblies, while the Others have seven. However, due to the fact that the number of delegates for constituent peoples has been reduced from 30 to 17 , based on a decision imposed by the OHR in 2002, cantonal assemblies with Bosniak majorities could potentially appoint 35 of the total of 54 delegates (65\%), while Croat-majority assemblies could only appoint 11 of the total 17 delegates (20\%) (Table 1).

In cantonal assemblies, Serbs and Others have even fewer possibilities of appointing their legitimate delegates from Bosniak and Croat majority cantons. In fact, 12 of the 17 Serbs have been elected from Bosniak-majority cantonal assemblies, three from Croat-majority cantonal assemblies and two from mixed cantons (Table 1). Since Serbs are a minority in all cantonal assemblies, it often happened that Bosniak and Croat majorities elected either their Serb-puppets or ethnic Bosniaks or Croats who simply declare themselves as Serbs to the Federation's House of Peoples ( $\mathrm{Vu}-$ koja 2013: 98-99), a practice which was legal according to the Election Law until 2016.

This kind of discrimination based on this type of outvoting has led to serious outbreaks. For instance, in 2010 six of the 17 delegates in the Croat caucus were elected in cantonal assemblies with Bosniak majorities (Vukoja 2013: 99). Considering the Election Law changes and the decision of the international community, this was sufficient to appoint the Government and the President of the Federation without considering the votes of the majority in the Croat caucus, which undoubtedly posed serious questions over the existence of consociational arrangements in practice. Indeed, until the OHR's amendments in 2002 regarding the nomination of the President and Vice-Presidents, the Constitution of the Federation prescribed:

"In electing the President and Vice-President, a caucus of the Bosniak Delegates and a caucus of the Croat Delegates to the House of Peoples shall each nominate one person. Election as President and Vice-President shall require approval of the two nominees jointly by a majority vote in the House of Representatives, then by a majority vote in the House of Peoples, including a majority of the Bosniak Delegates and a majority of the Croat Delegates".

\section{After 2002:}

"Article IV.B.2: In electing the President and two Vicepresidents of the Federation, at least one third of the delegates of the respective Bosniak, Croat or Serb caucuses in the House of Peoples may nominate the President and two Vice-presidents of the Federation".

Thus, by controlling six of the 17 delegates to the Croat caucus, 12 of the 17 
to the Serb caucus and five of seven to the Others', Bosniak politicians are able to influence the election of Federation's executive. ${ }^{16}$

Following these dysfunctions, the Constitutional Court reached its decision in 2016. Contrary to the ECHR, which kept the focus on "individual rights", the "Constitutional Court recalls that according to the general principle of democracy, the right to participate in democratic decision-making is exercised through legitimate political representation, which has to be based on the democratic choice of those represented and whose interests are represented" (Constitutional Court of B-H 2016: \$47). Moreover, the Court recalls that "the connection between those who are represented and their political representatives at all administrative-political levels is actually the one that gives the legitimacy to community representatives" as well as that "the House of Peoples is not the house of federal units but the house of constituent peoples" (\$50). This way, the Court chose to preserve the link between the electors (those represented) and their representatives elected through legitimate political representation. Therefore, when deciding on B-H Election Law, the Constitutional Court judged that such an election of delegates (that involves the principle that "all constituent peoples are given one mandate

16 It almost happened in 2011, but a delegate elected from a Bosniak canton, Elvira Abdić Jelenović, openly refused to take part in the engineering in order to favour the creation of a moderate civic coalition. She was sanctioned by her political party Democratic People's Union (Klix 2011). However, the engineering was concluded by the OHR, which implemented the "Platforma" coalition led by SDP (Index.hr 2011). On the other hand, if the number of constituent peoples' delegates had remained the same as until 2002, or more then 17 , the possibility of controlling one third of the Croat caucus would definitely have been minor. in each canton") could not be democratic: political representation cannot be legitimate because those represented and their interests are not guaranteed to be acknowledged.

Finally, although some Croat-majority cantonal assemblies select delegates by outvoting Bosniaks, the fact that Bosniaks are able to select six of the 17 Croats, but also 12 of the 17 Serbs and five of the seven Others to the House of Peoples (Table 1) permits them to form the Government of the Federation and to appoint the entity's president. Negative consequences are thus felt mostly by Croats within the Federation, who, contrary to Serbs, do not have their own entity within $\mathrm{B}-\mathrm{H}$, and by the Others. The Constitutional Court decided that such practice is unconstitutional because it represents an example of undemocratic illegitimate political representation, indicating that the main consociational principles have been neglected.

\section{Proposals of Election Law reform by $\mathrm{B}-\mathrm{H}$ political actors}

Since the delivery of the ECHR's judgments, B-H political actors have not given any proposals concerning the implementation of these judgments. Similarly, as a consequence to the Constitutional Court decisions, the political scene in B-H is split along ethnic lines between the Croats and the Bosniaks, reflecting the same divergence that has persisted since the 1990s.

\section{The Croat proposal}

The leading B-H Croat political coalition HNS submitted its proposal (HNS 2017) on amendments to the B-H Election Law to the Parliamentary Assembly of B-H on 28 April 2017. The proposal is based on an ethno-territorial model and includes the rules for the election of 
the Presidency of B-H, the Federation's House of Peoples as well as the executive authorities of the City of Mostar. ${ }^{17}$

For the election of the two presidents (Bosniak and Croat), the model suggests the creation of electoral areas A, B and C defined as one constituency of the Federation. The electoral area $\mathrm{A}$ would be composed of municipalities with more than a $2 / 3$ Bosniaks population. The electoral area B would be composed of municipalities in which there are more than $2 / 3$ of Croats. The electoral area $\mathrm{C}$ would be composed of municipalities in which Bosniaks and Croats do not make up $2 / 3$ of the population. The Bosniak member would be elected if they win the highest number of votes within the Federation if the sum of votes in areas $\mathrm{A}$ and $\mathrm{C}$ is greater than those in $\mathrm{B}$ and C. The same goes for the Croat member, except that they must win more votes in $\mathrm{B}$ and $\mathrm{C}$ than in $\mathrm{A}$ and $\mathrm{C}$.

Concerning the House of Peoples, the Croat proposal accepts abolishing the Election Law Article 20.16.A (a-j), as well as a part of Article 10.12(2) ("all constituent peoples are given one mandate in each canton"). This part of Article 10.12(2) would remain deleted, while Article 20.16.A (a-j) would be based on the most recent population census and would stipulate the number as well as the way in which delegates are elected to the House of Peoples: 17 Bosniak delegates would be appointed from the cantonal assemblies of seven Bosniak-majority and mixed cantons, 17 Croat delegates would be appointed from the cantonal assemblies of seven Croat-majority and mixed cantons. Similarly, 17 Serb and seven delegates of Others would be nominated from cantonal assemblies where a relevant number of the listed peoples exist. The main argument used by Croat parliamentarians is that

17 The election rule for the City of Mostar is not to be analysed yet. this would guarantee legitimate political representation (HNS 2017).

The proposal was accepted by the House of Peoples of the Parliamentary Assembly of B-H on 19 July 2017. Of the 15 delegates composed of five members for each constituent people, five Croat and three Serb members voted in favour of the bill, whereas four Bosniaks voted against it (Parliamentary Assembly of B-H 2017). Nonetheless, on 31 January 2018 the House of Representatives, composed of 42 members elected by proportional representation, rejected the proposal with 29 votes against and 11 in favour, which meant that the Croat proposal was rejected by the state's parliament (Parliamentary Assembly of B-H 2018).

\section{The Bosniak proposal}

Bosniak parties made two proposals. The first was proposed by the main Bosniak party, SDA, on 15 November 2017. The SDA submitted its draft to the Parliamentary Assembly of B-H. Contrary to the Croats, the SDA did not try changing the rules for the election of the Presidency. Rather, it proposed a model for the distribution of seats in the Federation's House of Peoples and for the election in the City of Mostar. Concerning the House of Peoples, the SDA proposal ignored the decision of the Constitutional Court. The proposal was based on 1991 population census and insisted on the re-implementation of some parts annulled by the Court, including Article 10.12(2) (Election Law 2018, Source. ba 2017). It was rejected on 31 January 2018 in the House of Representatives by 33 votes against and seven in favour. All Serb and Croat representatives, as well as some non-SDA members voted against the proposal (Parliamentary Assembly of B-H 2018). 
The second, proposed by a coalition of civic parties including SDP, Democratic Front (DF) and Our Party (Naša Stran$k a$ ), whose voters are mainly Bosniaks (Bieber 2006: 105; Caspersen 2004: 575; Hulsey 2016: 57), ${ }^{18}$ has been supported by the conservative SBB and SDA. Contrary to the Croat and SDA proposals, this coalition did not submit a proposal of amendments to the Election Law to the state's parliament, but to the Federation's Parliament. Indeed, on 19 June 2018 this large coalition of Bosniak parties submitted the proposal of the "Law on Constituencies and Number of Mandates of the Parliament of the Federation of Bosnia and Herzegovina" to the Federation's Parliament. This proposal changed some boundaries and the number of seats for each constituency in the House of Representatives and it prescribed the number of seats for the House of Peoples. The proposal contains provisions that increase majoritarian ones both in the House of Representatives and in the House of Peoples (Parliament of the Federation of B-H 2018).

Concerning the House of Representatives, the Bosniak coalition proposes new constituencies and the number of mandates, which should change at least every 10 years, based on the size of the population, the number of citizens with residence permits (including minors), registered voters as well as geographical,

18 SDP and Komšić are largely supported and voted by Bosniaks (Bose 2005; Bieber 2006: 105; Caspersen 2004: 575; Hulsey 2016: 56-57). Hulsey (2016: 57), however, argues that Naša stranka "emerged to offer an alternative to ethnic politics that is neither burdened by the socialist past of the SDP nor the history of Bosniak support". Its leader Boriša Falatar ran as a candidate for the Croat seat to the Presidency of B-H in the 2018 general election. He campaigned in many Croat-majority municipalities and sent clear messages that he is a candidate for all, including Croats, while criticizing candidates to the Croat seat who sought only Bosniak votes (N1 2018). administrative and historical criteria. According to the proposal, the number of representatives of Bosniaks as the most numerous constituent people would increase, whereas the number of other ethnic groups would decrease. For instance, taking into account the 2014 general election results in relation to the Bosniak proposal the following cases would be possible in constituencies: (a) where the number of deputies in the House of Representatives would remain the same, the Croats would have won 4 of the possible 27 (14.8\%) mandates; (b) where the number of deputies in the House of Representatives would increase, Croats would have won 1 of the possible $22(4.6 \%)$ mandates; (c) where the number of deputies in the House of Representatives would decrease, Croats would have won 10 of the possible 24 (41.7\%) mandates (calculation based on: Central Election Commission 2014).

Concerning the House of Peoples, the Bosniak proposal did not consider decision U-23/14 of the Constitutional Court. In fact, it maintained exactly the same model of election and number of delegates from each constituent people and Others, in all cantonal assemblies. Nevertheless, Bosniaks defended the design of the law stating that it is based on the Constitution of Federation of $\mathrm{B}-\mathrm{H}$, regardless of the fact that it is not in line with the Constitutional Court U-23/14 decision. Effectively, the Court expressed itself on the state Election Law and not on the Federation's Constitution that still contains the provision that all constituent peoples are given one mandate in each canton, ${ }^{19}$ which is not

19 Article IV.A.2.8(3) of the Constitution of the Federation of $\mathrm{B}-\mathrm{H}$ prescribes: "In the House of Peoples there shall be at least one Bosniak, one Croat, one Serb from each Canton which has at least one such delegate in its legislative body". This article was changed in 2002 by the High Representative Wolfgang Petritsch's Amendment XXXIV. 
in line with the Constitutional Court decision (Parliament of the Federation of B-H 2018).

\section{The Serb position}

Serbs are the least numerous constituent people within the Federation $(2.5 \%$ of the population) affected by the Election Law in an unconstitutional manner. Although the Serbs have expressed concern on the fact that their delegates can be controlled by either Bosniak or Croat majorities in cantonal assemblies (Table 1), Serb parties and organisations have kept a distance without giving concrete amendment proposals. This can be also interpreted by the fact that Serbs have "their own" entity which tries to defend interests of all compatriots (Vecernji.hr 2018).

In the Parliamentary Assembly their voting depends on their coalition with Bosniak and Croat parties at state level. The largest Serb party, Milorad Dodik's Alliance of Independent Social Democrats (SNSD), publicly expressed its full support to the HNS proposal (Al Jazeera 2017) and voted in favour in both chambers, while Serb opposition members voted against the HNS proposal in the lower and abstained in the upper chamber. On the other hand, all Serb parties voted against the SDA proposal (Parliamentary Assembly 2017, 2018).

\section{Proposals by non-governmental domestic actors}

Proposals for changes of electoral rules by non-governmental domestic actors have been publically presented and discussed, but remain unimplemented.

Only few proposals were presented by domestic intellectuals and scholars. The first appeared in 2013, after U.S. Ambassador Patrick Moon gathered Bosniak and Croat professors and intellectuals, known as the Expert Group. ${ }^{20}$ They presented 181 norms for constitutional reforms, which included a proposal for the modification of the decision-taking mechanism in the federal parliament. Indeed, item 55 on the draft presented on 7 May 2013 describes the role and relations between the two houses of parliament (Vukoja 2013: 99-100):

"The houses have separate sessions in which they decide about the issues that are discussed at a joint session. The House of Representatives decides by the majority of votes of its members, while the House of Peoples with the majority of delegates' votes, which include most Bosniak, most Croat and most Serb delegates".

However, the content of this proposal was changed "in dubious circumstances" and as such presented to the Parliament of the Federation on 29 May 2013. The content of the proposal sent to the state Parliamentary Assembly differs in its substance. Indeed, it prescribes that:

"The houses make decisions about the matters proposed at joint sessions in equal competencies but at separate sessions, in accordance with the Constitution and the rules of procedure of the houses".

As in the greatest espionage stories, nobody knows who changed the original version. This created confusion among the authors and politicians who have refused to consider the proposal

20 The Expert Group was composed of Kasim Trnka (former Law Professor and judge at the Constitutional Court), Vahid Šehić (political analyst and Chairman of the Forum of Citizens of Tuzla), Mirjana Nadeždin-Defterdarević (Law Professor, University of Sarajevo), Mile Lasić (Political Science Professor, University of Mostar) and Krešimir Zubak (former president of the wartime Herzeg-Bosnia, Federation of $\mathrm{B}-\mathrm{H}$ and first Croat member of the Presidency of B-H). 
of the Expert Group. ${ }^{21}$ This substantial change reflects the crucial political divergence between Bosniaks and Croats. Indeed, in the first version, parliamentary decisions are taken by a simple majority in the House of Representatives and by majorities of all the three national caucuses in the House of Peoples. On the other hand, the second version submitted to the analysis of parliamentarians stated that decisions are taken by simple majorities in both the House of Representatives and House of Peoples. The Croats protested because the second version enabled Bosniaks to control all legislative mechanisms since they could potentially dominate both houses of the Parliament.

The second proposal by civil society actors was drafted by the Institute for Social and Political Research (IDPI) and presented in Mostar on 8 June 2018. The IDPI is a domestic nonpartisan and independent think--tank whose mission is to enhance and develop expertise in the field of state organisation and governance. Its proposal is based on four basic principles: upholding the Dayton constitution, protection of the constituent peoples' equality, the implementation of the Constitutional Court ruling and the possibility to participate and become a candidate for all levels of government during elections. The proposal offers different models for the election of the Federation's House of Peoples. One of them concerns the organisation of four Grand Electoral Colleges, composed of cantonal assemblies' members, which elects delegates to their own group in the House of Peoples (IDPI 2018).

21 Speculations over the motives and actors of the modification of Expert Group's document created a sort of debate which divided the members and ended the existence of this group.

\section{Criticisms of the proposals}

Instead of sparking off a substantial debate, the proposals were heavily criticised and politicised. Criticisms of the proposal reflect the ethnic lines as well as attitudes of Bosniaks and Croats on the state and its political system since 1990s. As summarised by Kasapović (2018: 254), "Bosniaks support a radical review of the constitutional order which would transform B-H from an asymmetrical consociational (con)federation into a unitary liberal state". On the other hand, Croats defend consociational arrangements "in the Federation as well as in the state since both political communities are in minority".

Some hardliner Bosniak leaders deemed the Croat proposal a step toward "the renewal of wartime Herzeg-Bosnia", "partition of Bosnia" and an attempt to reach "the ultimate goal of provoking organised violence" (Jabuka.tv 2017). Šefik Džaferović, the SDA's current member of the B-H Presidency, gives a more moderate comment on the Croat proposal. First, he believes that the Croats "practically confirm and deepen discrimination already determined by the decisions of the ECHR", because they do not adhere to its regulations. Džaferović adds that they also "bring in additional ethnic divisions" and, finally, that they are not treating the federal constitution with respect because they do not respect the provision which stipulates that "from each canton, at least one representative of each constituent people must be delegated to the federal House of Peoples, if elected in cantonal legislative bodies" (SDA 2017). Furthermore, the SDA asked the Constitutional Court whether the HNS proposal was against Bosniaks' vital national interests. The Court rejected the SDA's appeal, arguing that the HNS proposal is in compliance with the constitution (Constitutional Court of B-H 2017). To sum up, 
the main arguments used to criticise the proposal are related to seeking greater "ethnical division" within B-H and their "disrespect" of the federal constitution.

On the other hand, the Croats complain that Bosniak proposals do not conform to the state's constitution. Croat politicians accuse Bosniaks of "breaking the state, because they are trying to abolish state level powers" (Dnevnik.ba 2018). Also, it could be argued that Bosniaks are doing everything in order to dissociate from the Dayton agreement and that their programmes have been "profiled as de facto anti-systemic and anti-constitutional actors" (Kasapović 2018: 255). Croat representatives argue that the Bosniaks and the international community are predominantly trying "to enforce political interpretations instead of legal ones, and here we are talking about the implementation of the Constitutional Court's decision" (Peacefare.net 2018). Furthermore, according to Croat public opinion, the Bosniaks are seeking to establish their own entity, like the Serbs in B-H, but without the Croats (Jabuka.tv 2018). When it comes to the content of the proposals, the Croats find them illegal, because they took unconstitutional rules of the Election Law and tried to apply them in the law.

\section{Conclusion}

Since the 1990s, the fate of the political system in B-H has depended on fixed national positions of the three constituent peoples. There is no consensus when it comes to the future of this type of democracy and political system. Using the example of Bosniak-Croat relations, article shows that the main liberal criticism of consociation, expressed by some international and domestic figures who seek to abolish consociational arrangements, has also been marked by different understandings of democracy. Bosniak elites do not accept consociational arrangements, and they prefer majoritarian rules, whereas the Croats seek to preserve consociation without accepting the centralization of power. In each other's eyes, some forms of democracy are unacceptable if they do not fit exactly into their views. The Bosniaks do not accept consociation principles as a form of democracy, arguing that the Croats are over-represented. On the other hand, the Croats perceive both Bosniak civic and conservative parties' majoritarian goals as their intention to apply domination, which is consequently rejected as a form of democracy because it is disrespectful of less numerous constituent groups' interests.

The Constitutional Court decision on the Election Law showed that the most numerous constituent people will not accept any attempt of power-sharing, while the less numerous constituent people seek to introduce a rule that also considers the territorial principle for amending the Election Law. Accordingly, proposals made by Bosniaks showed that they try to preserve the majoritarian rules for the election of common institutions, especially for the federal upper house in which each national community should have the possibility of defending its specific interests. On the other hand, the Croats proposed electoral rules based on territoriality seeking to preserve and guarantee consociational norms. In other words, "the current consensus on democracy is only principled since the three sides deeply disagree on whether B-H should have a liberal or consociational political order and whether it should be a democratic federation or a unitary state" (Kasapović 2018: 254).

Finally, the article showed that the international community has changed its initial approach from supporting and imposing consociational arrangements to promoting integrationist-like rules. 
Having in mind the described example of the Election Law of B-H applied to Bosniak-Croat relations, this article showed that consociation is particularly targeted by critics, both in theory and practice, as an "illegitimate" form of democracy. On the other hand, it seems that the Election Law's lesson and Constitutional Court's judgment on defining legitimate democratic representation fit Lijphart's (2018: 9) words - which defend consociation as "more conducive to peaceful co-existence and probably also more fair and legitimate (as was recognised in Iraq and the former Yugoslavia)". 


\section{Bibliography}

Adams, Tom W. 1966. The First Republic of Cyprus: a review of an unworkable constitution. Western Political Quarterly. (19) 3: 475-490.

Agreement on Friendship. 1992. Agreement on Friendship and Cooperation between Bosnia and Herzegovina and Croatia. In: Trifunovska, Snežana. (ed.). 1994. Yugoslavia Through Documents: From Its Creation to Its Dissolution. Dordrecht: Martinjus Njihoff Publishers, pp. 656-658.

Al Jazeera. 2017. Dodik podržao Čovića u promjeni Izbornog zakona. Published online: 12 July 2017 . http://balkans.aljazeera.net/vijesti/dodik-podrzao-covica-u-promjeni-izbornogzakona.

Arlović, Mato. 2017. THrvatska zajednica Herceg-Bosna $i$ (re)organizacija Bosne $i$ Hercegovine. (The Croatian Community of Herzeg-Bosnia and the /re/organisation of Bosnia and Herzegovina. Zagreb: Novi informator.

Belloni, Roberto. 2004. Peacebuilding and Consociational Electoral Engineering in Bosnia and Herzegovina. International Peacekeeping. (11) 2: 334-353. DOI: 10.1080/ 1353331042000237300

Belloni, Roberto. 2007. State Building and International Intervention in Bosnia. London: Routledge. DOI: 10.4324/9780203938003

Bennett, Christopher. 2016. Bosnia's Paralysed Peace. London: Hurst Publishers.

Bieber, Florian. 2001. Croat Self-Government in Bosnia - A Challenge For Dayton? European Centre for Minority Issues Brief No. 5, May 2001. http://edoc.vifapol.de/opus/volltexte/2009/1991/pdf/brief_5.pdf.

Bieber, Florian. 2006. Post-War Bosnia: Ethnicity, Inequality and Public Sector Governance. New York: Pal- grave Macmillan \& UNRISD. DOI: 10.1057/9780230501379

Bose, Sumantra. 2002. Bosnia after Dayton. Nationalist Partition and International Intervention. Oxford: Oxford University Press.

Bose, Sumantra. 2005. The Bosnian State a decade after Dayton. International Peacekeeping. (12) 3: 322-335. DOI: $10.1080 / 13533310500074028$

Bunta, Finnian James. 2018. Bosnia's Paradox: The Irony of External Pressure within Consociational Democracy. Senior Theses Lake Forest College Publications. https://publications.lakeforest.edu/cgi/viewcontent. cgi? article $=1128 \&$ context $=$ seniortheses.

Burg, Steven L., Shoup, Paul S. 1999. The War in Bosnia-Herzegovina: Ethnic Conflict and International Intervention. London: M. E. Sharpe.

Caspersen, Nina. 2004. Good Fences Make Good Neighbours? A Comparison of Conflict-Regulation Strategies in Postwar Bosnia. Journal of Peace Research. (41) 5: 569-588. DOI: $10.1177 / 0022343304045973$

Central Election Commission. 2000. Potvrđeni rezultati Općih izbora 2000. godine. Published online: unavailable. http://www.izbori.ba/Documents/ Documents/Rezultati\%20izbora\%20 96-2002/2000gen/fbihhor-eng.pdf

Central Election Commission. 2010. Potvrđeni rezultati Općih izbora 2010. godine. Published online: 11 November 2010. http://www.izbori. ba/Finalni2010/Finalni/ParlamentFBIH/ZbirniRezultate.aspx.

Central Election Commission. 2014. Potvrđeni rezultati Općih izbora 2014. godine. Published online: 10 November 2014. http://www.izbori.ba/Potvrdjeni2014/Finalni/ParlamentFBIH/ Default.aspx. 
Constitution of the Federation of B-H. 2011. Constitution of the Federation of $\mathrm{BiH}$ (with amendments). http:// www.bihdaytonproject.com/wp-content/uploads/2011/06/fbih-constitution.pdf.

Constitutional Court of B-H. 2016. Decision U-23/14. Published online: 1 December 2016. http://www.ustavnisud.ba/dokumenti/_en/U-23-141058444.pdf.

Constitutional Court of B-H. 2017. Judgment U-3/17. Published online: 6 July 2017. http://www.ustavnisud.ba/ dokumenti/_bs/U-3-17-1081849.pdf.

Dnevnik.ba. 2018. Jozo Bagarić: Mislio sam da je ovo početak kraja (Federacije). Published online: 19 January 2018. https://www.dnevnik.ba/teme/jozo-bagaric-mislio-sam-da-je-ovo-pocetak-kraja-federacije.

ECHR. 2014. Case of Zornić v. Bosnia and Herzegovina, final. Published online: 15 December 2014. https:// hudoc.echr.coe.int/eng\#\{\%22item id\%22:[\%22001-145566\%22]\}.

Efendić, Kenan. 2013. Bosnia Solves "Croat Question" at Sejdic-Finci's Expense. Published online: 29 March 2013. http://www.balkaninsight.com/ en/article/bosnia-solves-croat-question-at-sejdic-finci-s-expense.

Election Law. 2018. Election Law of Bosnia and Herzegovina. https://www.izbori.ba/Documents/documents/ZAKONI/BiH_Election_Law_last_consolidated_version_2018.pdf.

Faktor.ba. 2017. Svi su uz Čovića i Hrvatski narodni sabor $\mathrm{BiH}$ : Koje se stranke u BiH zalažu za Hrvatsku do Drine. Published online: 19 September 2017. https://faktor.ba/vijest/svesu-uz-covica-i-hrvatski-narodni-sabor-bih-koje-se-stranke-u-bih-zalazuza-hrvatsku-do-drine-263804.

Foreign Policy. 2018. Bosnia Is Teetering on the Precipice of a Polit- ical Crisis. Published online: 21 March 2018. https://foreignpolicy. com/2018/03/21/bosnia-is-teeteringon-the-precipice-of-a-political-crisisbalkans-election-law-dodik/.

Fraenkel, Jon, Grofman, Bernard. 2006. Does the alternative vote foster moderation in ethnically divided societies? The case of Fiji. Comparative Political Studies. (39) 5: 623-651. DOI: $10.1177 / 0010414005285032$

Friedman, Francine. 1996. The Bosnian Muslims: Denial of a Nation. Boulder: Westview Press.

Friedman, Francine. 2004. Bosnia and Herzegovina: A Polity on the Brink. London \& New York: Routledge. DOI: 10.4324/9781315887791

FZS. 2013. Federalni zavod za statistiku: Popis stanovništva, domaćinstava i stanova u Bosni i Hercegovini 2013. godine. Stanovništvo prema etničkoj/ nacionalnoj pripadnosti, po mjesnim zajednicama. https://view.officeapps. live.com/op/view.aspx?src=http://fzs. ba/wp-content/uploads/2018/07/Stanovn_etnik_MZ.xlsx.

Harland, David. 2017. Never again: International intervention in Bosnia and Herzegovina. Centre for Humanitarian Dialogue Publications. Published online: 26 July 2017. https:// www.hdcentre.org/wp-content/uploads/2017/07/Never-again-International-intervention-in-Bosnia-and-Herzegovina.pdf.

Hayden, Robert M. 2005. 'Democracy' without a Demos? The Bosnian Constitutional Experiment and the Intentional Construction of Nonfunctioning States. East European Politics and Societies. (19) 2: 226-259. DOI: $10.1177 / 0888325404272679$

HNS. 2017. Prijedloga Zakona o izmjenama i dopunama Izbornog zakona BiH. Published online: 28 April 2017. http://www.hnsbih.ba/wp-content/ 
uploads/2017/10/prijedlog-zakona-o-izmjenama-i-dopunama-izbornog-zakona-bih.pdf.

Hoare, Attila Marko. 2007. The History of Bosnia: From the Middle Ages to the Present Day. London: Saqi Books.

Hoare, Attila. 1997. The Croatian project to partition Bosnia-Hercegovina, 1990-1994. East European Quarterly. (31) 1: 121-138. Expanded Academic ASAP. http://link.galegroup.com/ apps/doc/A19389882/EAIM?u=hei\&sid=EAIM\&xid=7cae9e55.

Horowitz, Donald. 1985. Ethnic Groups in Conflict. Berkeley: University of California Press.

Hulsey, John. 2016. Party Politics in Bosnia and Herzegovina. In: Keil, Soeren, Perry, Valery. (eds.). State-Building and Democratization in Bosnia and Herzegovina. New York: Routledge, pp. 41-60.

ICG. 1999. Is Dayton Failing? Bosnia Four Years after the Peace Agreement. Sarajevo ICG Balkans Report $\mathrm{N}^{\circ} 80$, 28 October 1999. https://d2071andvip0wj.cloudfront.net/is-dayton-failing. pdf.

IDPI. 2018. A proposal for the implementation of the Constitutional Court of $\mathrm{BiH}$ "Ljubić" ruling for the House of Peoples of the Parliament of the Federation of $\mathrm{BiH}$. Published online: 11 December 2018. http:// www.en.idpi.ba/wp-content/uploads/2018/12/IDPI-Reform-Federation-House-of-Peoples.pdf.

Index.hr. 2011. Valentin Inzko ukida odluke CIK-a: Na pomolu nova politička kriza u BiH? Published online: 28 March 2018. https://www.index.hr/ vijesti/clanak/valentin-inzko-ukida-odluke-cika-na-pomolu-nova-politicka-kriza-u-bih/544386.aspx.

Jabuka.tv. 2017. Građanski savez: HDZ i Čović spremaju nasilje. Published online: 19 April 2017. https://www.ja- buka.tv/gradanski-savez-hdz-i-covicspremaju-nasilje/.

Jabuka.tv. 2018. Lučić: Bošnjaci Federaciju pretvaraju u svoj entitet, ali Hrvati neće pokleknuti. Published online: 19 June 2018. https://www. jabuka.tv/lucic-bosnjaci-federaciju-pretvaraju-u-svoj-entitet-ali-hrvati-nece-pokleknuti/

Kasapović, Mirjana. 2016. Lijphart and Horowitz in Bosnia and Herzegovina: institutional design for conflict resolution or conflict reproduction? Croatian Political Science Review. (53) 4: 174-190.

Kasapović, Mirjana. 2018. The Relationship between Peace, State and Democracy: Bosnia and Herzegovina as a Deviant Case. Teoria polityki. 2: 249-260. DOI: 10.4467/25440845TP.18.014.8449

Keil, Soeren. 2012. Federalism as a tool of conflict resolution: the case of Bosnia and Herzegovina. L'Europe en Formation. (54) 363: 205-218. DOI: 10.3917/eufor.363.0205

Klix.ba. 2011. DNZ pokrenuo postupak protiv Elvire Abdić-Jelenović. Published online: 20 March 2011. https:// www.klix.ba/vijesti/bih/dnz-pokrenuo-postupak-protiv-elvire-abdic-jelenovic/110320047.

Legislative Decree. 1992. Legislative Decree on Amendments to the Decree on Armed Forces of the Republic of Bosnia and Herzegovina. In: Šiber, Stjepan (ed.). 2000. Prevare, zablude, istina. Ratni dnevnik 1992. Sarajevo: Rabic, pp. 306-307.

Lijphart, Arend. 1969. Consociational Democracy. World Politics. (21) 2: 207-225.

Lijphart, Arend. 1977. Democracy in Plural Societies: A Comparative Exploration. New Haven: Yale University Press. 
Lijphart, Arend. 1979. Consociation and Federation: Conceptual and Empirical Links. Canadian Journal of Political Science / Revue canadienne de science politique. (12) 3: 499-515.

Lijphart, Arend. 1995. Self-Determination versus Pre-Determination of Ethnic Minorities in Power-Sharing Systems. In: Kymlicka, Will. (ed.). The rights of minority cultures. Oxford: Oxford University Press, pp. 275-287.

Lijphart, Arend. 2018. Consociationalism After Half a Century. In: Jakala, Michaelina, Kuzu, Durukan, Qvortrup, Matt. (eds.). Consociationalism and Power-Sharing in Europe: Arend Lijphart's Theory of Political Accommodation. London: Palgrave Macmillan, pp. 1-9. DOI: 10.1007/978-3-31967098-0_1

Lučić, Ivo. 2013. Uzroci rata: Bosna $i$ Hercegovina od 1980. do 1992. godine. Zagreb: Hrvatski institut za povijest.

Malcolm, Noel. 1994. Bosnia: A Short History. New York: New York University Press.

Manning, Carrie. 2004. Elections and political change in post-war Bosnia and Herzegovina. Democratization. (11) 2: 60-86. DOI: 10.1080/ 13510340412331294212

Marijan, Davor. 2006. Sukob HVO-a i ABIH u Prozoru, u listopadu 1992. Časopis za suvremenu povijest. (38) 2: 379-402.

McCrudden, Christopher, O'Leary, Brendan. 2013a. Courts and Consociations, or How Human Rights Courts May De-stabilize Power-sharing Settlements? The European Journal of International Law. (24) 2: 477-501. DOI: $10.1093 /$ ejil/cht020

McCrudden, Christopher, O'Leary, Brendan. 2013b. Courts and Consociations: Human Rights Versus Power-Sharing. Oxford: Oxford University Press. DOI: 10.1080/18918131.2015.1000055
McCulloch, Allison. 2013. Does Moderation Pay? Centripetalism in Deeply Divided Societies. Ethnopolitics. (12) 2: 111-132. DOI: $0.1080 / 17449057.2012 .658002$

McCulloch, Allison. 2014. Power-Sharing and Political Stability in Deeply Divided Societies. New York: Routledge. DOI: $10.4324 / 9781315773698$

McGarry, John, O'Leary, Brendan. 2007. Iraq's Constitution of 2005: Liberal consociation as political prescription. International Journal of Constitutional Law. (5) 4: 670-698. DOI: 10.1093/ icon/mom026

Milanovic, Marko. 2010. Sejdic and Finci v. Bosnia and Herzegovina. American Journal of International Law. (104) 4: 636-641. DOI: 10.1017/ S1574019610200081

Mudry, Thierry. 1999. Histoire de la Bosnie-Herzégovine: faits et controverses. Paris: Ellipses (L'Orient politique).

N1. 2016. Profesionalni Bošnjaci, Hrvati i Srbi u institucijama BiH. Published online: 13 December 2016. http://ba. n1info.com/a127211/Vijesti/Vijesti/ Profesionalni-Bosnjaci-Hrvati-i-Srbiu-institucijama-BiH.html.

N1. 2018. Boriša Falatar pobijedio Dragana Čovića u 20 općina u BiH. Published online: 12 October 2018. http:// ba.n1info.com/Vijesti/a290641/Borisa-Falatar-pobijedio-Dragana-Covica-u-20-opcina-u-BiH.html.

O'Flynn, Ian. 2010. Democratic Theory and Practice in Deeply Divided Societies. Representation. (46) 3: 281-293. DOI: $10.1080 / 00344893.2010 .499696$

OHR. 1997. Peace Implementation Council Bonn Conclusions. 10 December 1997. http://www.ohr.int/?p=54137.

Parliament of the Federation of B-H. 2018. Prijedlog Zakona o izbornim jedinicama i broju mandata Parlamenta Federacije Bosne i Hercegovine. http://www.parlamentfbih.gov. 
ba/dom_naroda/v2/userfiles/file/ Materijali\%20u\%20proceduri_2018/ Prijedlog\%20zakona\%20o\%20izbornim\%20jedinicama.pdf.

Parliamentary Assembly of B-H. 2017. 31. sjednica Doma naroda Parlamentarne skupštine $\mathrm{BiH}$. Published online: 19 July 2017. http://static.parlament.ba/doc/101667_Glasanje\%2031. sjednice\%20DN19072017.pdf.

Parliamentary Assembly of B-H. 2018. 55. sjednica Zastupničkog doma Parlamentarne skupštine Bosne i Hercegovine. Published online: 31 January 2018. http://static.parlament.ba/ doc/107411_Glasanja_nastavka_55_ sjednice_PD_31_01_2018.pdf.

Peacefare.net. 2018. Croatian Assembly of Bosnia says I'm wrong. Published online: 4 May 2018: https://www. peacefare.net/2018/05/04/the-croatian-assembly-of-bosnia-says-imwrong/.

Pepić, Ivan, Kasapović, Mirjana. 2018. The Gradual Cyprusization of the Federation of Bosnia and Herzegovina: Structural, Institutional and Process Assumptions. Journal of Balkans and Near Eastern Studies. Published online: 5 September 2018: https://www.tandfonline.com/doi/fu 1l/10.1080/19448953.2018.1506289? scroll=top\&needAccess $=$ true. $\quad$ DOI: 10.1080/19448953.2018.1506289.

Pogled.ba. 2011. SDA: Priopćenje Vlade ŽS-a nije u skladu s dogovorom koalicionih partnera. Published online: 20 May 2011. http://m.pogled.ba/clanak/ sda-priopcenje-vlade-zs-a-nije-u-skladu-s-dogovorom-koalicionih-partnera/25128.

Ramet, Sabina. 2006. The Three Yugoslavias: State-building and Legitimation, 1918-2005. Bloomington: Indiana University Press. DOI: 10.1017/ CBO9780511491108
Reilly, Benjamin. 2001. Democracy in Divided Societies: Electoral Engineering for Conflict Management. Cambridge: Cambridge University Press.

Reilly, Benjamin. 2012. Institutional Designs for Diverse Democracies: Consociationalism, Centripetalism and Communalism compared. European Political Science. (11) 259-270. DOI: 10.1057/eps.2011.36

Sartori, Giovanni. 1968. Political Development and Political Engineering. In: Montgomery, John D. and Hirschman, Albert O. (eds.). Public Policy. Cambridge: Harvard University Press, pp. 261-298.

SDA. 2017. Džaferović: Za SDA neprihvatljiv prijedlog izmjena i dopuna Izbornog zakona $\mathrm{BiH}$. Published online: 10 November 2017. http://sda.ba/ home/dzaferovic-za-sda-neprihvatljiv-prijedlog-izmjena-i-dopuna-izbornog-zakona-bih/.

Shrader, Charles R. 2003. The Muslim-Croat Civil War in Central Bosnia: a military history, 1992-1994. College Station: Texas A\&M University Press.

Šiber, Stjepan. 2000. Prevare, zablude, istina. Ratni dnevnik 1992. Sarajevo: Rabic.

Source.ba. 2017. SDA uputila svoj Prijedlog Izbornog zakona. Published online: 17 November 2017. http:// www.source.ba/clanak/BiH/452670/ SDA-uputila-svoj-Prijedlog-Izbornog-zakona.

Stojanović, Nenad. 2018. Political marginalization of 'Others' in consociational regimes. Zeitschrift fur Vergleichende Politikwissenschaft. (12) 2: 341-364. DOI: 10.1007/s12286-0170375-4

Tabeau, Ewa, Bijak, Jakub. 2005. War-related Deaths in the 1992-1995 Armed Conflicts in Bosnia and Herzegovina: A Critique of Previous Estimates and Recent Results. European Jour- 
nal of Population / Revue européenne de Démographie. (21) 2-3: 187-215. DOI: $10.1007 / \mathrm{s} 10680-005-6852-5$

The Guardian. 2018. Complacent Europe not ready for another Balkan meltdown. Published online: 6 October 2018. https:/www.theguardian.com/ world/2018/oct/06/complacent-europe-balkans-meltdown-russia.

Trifunovska, Snežana. (ed.). 1994. Yugoslavia Through Documents:From Its Creation to Its Dissolution. Dordrecht: Martinjus Njihoff Publishers.

Van Willigen, Niels. 2010. From Nation-building to Desecuritization in Bosnia and Hezergovina. Security and Human Rights. (21) 2: 127-138. DOI: 10.1163/187502310791305864

Vecernji.hr. 2018. Hrvati više ne smiju biti žrtva izbornog inženjeringa. Published online: 12 January 2018. https:// www.vecernji.hr/vijesti/bih-zeljkokomsic-hrvati-vise-ne-smiju-biti-zrtva-izbornog-inzenjeringa-1219213.
Vukoja, Ivan. 2013. Primjeri ne-konstitutivnosti i ne-jednakopravnosti Hrvata u Federaciji BiH. Status. 16: 92-108.

Washington Agreement. 1994. Washington Agreement. https://www.usip. org/sites/default/files/file/resources/ collections/peace_agreements/washagree_03011994.pdf.

Wheatley, Steven. 2012. The construction of the constitutional essentials of democratic politics by the European Court of Human Rights following Sejdić and Finci. In: Examining Critical Perspectives on Human Rights. Dickinson, Rob et al. (eds.). Cambridge: Cambridge University Press. pp. 153-174. DOI: 10.1017/ CBO9781139026291.011

Zdeb, Aleksandra. 2016. The Need to Have Something 'Of Their Own': Croat Parallel Institutions in Bosnia and Herzegovina. Swiss Political Science Review. (22) 4: 545-564. 


\section{Rat drugim sredstvima? Shvaćanja demokracije i izborni zakon Bosne i Hercegovine}

Sažetak U članku se razmatraju politički učinci dvaju različitih shvaćanja demokracije u etnički duboko podijeljenim društvima na primjeru izbornog zakona Bosne i Hercegovine, a koje zastupaju političke elite bošnjačke i hrvatske zajednice u zemlji. U prvom dijelu članka objašnjava se sukob bošnjačke i hrvatske političke elite oko modela većinske i konsocijacijske demokracije koji traje od devedesetih godina 20. stoljeća. U drugom dijelu razmatraju se odluke Europskog suda za ljudska prava i Ustavnog suda Bosne i Hercegovine o izbornim pravilima. Tvrdi se da su institucionaliziranje centripetalističkih i suspendiranje konsocijacijskih aranžmana u izbornom zakonu povećali političke podjele među dvjema etničkim zajednicama. U trećem dijelu raspravlja se o prijedlozima izbornih pravila što su podastrijeti državnom i entitetskim parlamentima, koji potvrđuju postojanje nespojivih shvaćanja demokracije u bošnjačko-hrvatskoj Federaciji.

Ključne riječi Ustavni sud BiH, izborni zakon, bošnjačko-hrvatska Federacija, shvaćanja demokracije 